\title{
Application of Human Resource Systematic Management in Business Management
}

\author{
Wei Yangfan \\ Chengdu Aeronautic Polytechnic \\ hunter2011@foxmail.com
}

Keywords: Human resource; Systematic; Business management

\begin{abstract}
With the development of economy, global economy is integrating gradually, presenting the trend of globalization, and world economy is bound to form integration very soon. Under this economic development trend, competitions among industries are becoming increasingly fierce. In the final analysis, competitions among enterprises are competitions of talents. Therefore, in order to enhance enterprises' competitiveness among markets, bringing in high-quality talents is inevitable choice. Management of enterprise human resources is to maximize employees' abilities and finally increase the enterprise's competitiveness so that the enterprise can remain invincible in competitions. This paper first analyzes each aspect of human resource management, and then explains specific application measures of human resource systematic management in business management.
\end{abstract}

\section{Introduction}

In recent years, with the continuous development of Chinese economy and the acceleration of globalization, socialist economic construction has made striking achievements. Under this background, enterprises have obtained more profitable development space. In the meantime, they are facing more challenges inevitably. In order to maintain the enterprise's status in competitions, it should strengthen management of employees, which requires the enterprise to complete human resource management system continuously so that the enterprise's working efficiency gets improved continuously and achieve maximum market economic benefit[1]. Human resource management must make clear employees' responsibilities so that employees can learn to help each other, complete and promote the enterprise's development goals and further enhance the enterprise's management standard continuously and guarantee that the enterprise can have stable and healthy development.

\section{Definition of human resource management}

Human resource management means the process of recruiting, selecting, training, evaluating, reserving and using different groups of people and finally training high-quality employees [2]. Human resource management is a part of modern science and technology management, and its major contents are recruiting new employees and training them, allocating employees to suitable posts, finishing employees' performance assessment and salary administration and so on as well as analyzing employees' work. Human resource management must pay attention to usages of methods, and administrators must excavate employees' potentials, improve employees' enthusiasm, improve working efficiency and guarantee that each employee knows his own responsibility and has the ability to finish his own work.

\section{Differences between human resource systematic management and traditional personnel management}

The first difference is different emphasis. Traditional personnel management pays attention to different issues and they pay little attention to employees or employees' adaptation to work; while human resource systematic management treat employees as the center; they pay attention to 
employees' potentials and characteristics and allocate employees to posts where they can exert their abilities most and they pay attention to employees' regulation so as to guarantee that employees are full of working enthusiasm; also, they pay attention to employees' adaptation to work, which is of great promotion role to enterprises' economic benefits.

The second difference is different department relations. Traditional personnel management attaches to certain management department of the enterprise and other departments cannot supervise it; relations among departments are not close and there is little communication; human resource systematic management strengthens relation with other departments; each department coordinates each other so that human resource management standard improves continuously[3].

The third difference is different employees' roles. Employees under traditional personnel management are merely an investment cost of the enterprise, and they are viewed as an instrument to gain economic benefits any autonomous rights; enterprises under human resource systematic management have improved their understanding of employees; employees are regarded as a part of enterprise resources and they receive continuous training; finally, their qualities are improved and the enterprise's economic benefits are increased.

\section{Major goals of human resource management}

Expanding human capital. Enterprise resources mainly include manpower, financial and material resources and manpower resources are the most important resources. The existence of manpower resources can guarantee effective utilization of financial and material resources and the increase of enterprise's economic benefits. Therefore, enterprises must strengthen management of human resources and improve quality of the human resources so as to provide forceful reserve force for development of enterprises.

Enthusiasm efficiently. Some researches show that under most situations, employees have not exerted half of their actual abilities during work and most of them are because employees have not exerted enough working enthusiasm. Therefore, we can see that everyone's potentials are infinite and everyone has huge upside potential. Therefore, human resource administrators should pay attention to improving employees' working enthusiasm and stimulate employees' potentials. Improving enthusiasm can start from the following aspects, interpersonal relations and salary and treatment and so on[5].

Realizing maximization of corporate profit. Enterprise's economic benefit is necessary element for long development. Enterprises must improve management methods continuously, guarantee maximization of economic benefits, optimize human resource management system and improve enterprises' use ratio of human resource so as to help enterprises to realize maximum economic benefits and realize long-term and stable development.

\section{Functions of human resource systematic management to business management}

Functions of human resource systematic management to business management are divided into two aspects. Firstly, it contributes to enterprises' human resource management standard; the workload of business management is large and the tasks are various, and it is easy to influence business management quality [6]. Human resource management is one of the important constitutes of business management, so realizing systematization of human resource management can enhance employees' sense of belonging and improve working efficiency. In addition, high layers of enterprise can have a detailed and comprehensive understanding of human resources, reduce leaders' difficulty of business management; each department of enterprises can realize better coordination and employees' potentials can realize more development.

Besides, through optimization of salary, training mechanism, working environment and perspective of human resource management, it contributes to reducing wastage rate of talents, which is mainly because elements of human resource systematization optimization are all elements that lead to brain drain. Optimized human resource management offers more development 
opportunities to employees, and enterprise's administrators have increased their understanding to each employee so as to allocate employees’ work reasonably and reduce brain drain.

\section{Application measures of human resource systematic management in business management}

Formulating reasonable talents training plan. When formulating reasonable talents training plan, enterprises must consider demands of markets and enterprises' specific conditions. Only by this can guarantee reasonable effectiveness of the training plan. When formulating reasonable talents training plan, administrators should pay attention to the following points: firstly, they should pay attention to cultivation of employees' professional techniques since high-quality professional talents are of great promotion roles to enterprises; therefore, during training, besides some difficulties in work, more attention should be paid to employees' professional techniques; the higher employees' professional qualities, the higher the ability of solving problems, the less difficulties in work and the higher working efficiency, so enterprises' profits can be guaranteed. Secondly, when formulating reasonable talents training plan, administrators must have long-range vision. Some training plans may not have effects in a short term, but it can satisfy future development requirements and enterprises will achieve good economic benefits in future development. Thirdly, administrators should pay attention to excavating employees' potentials. Some employees' abilities are strong but can only be allocated to posts that do not suit their abilities. Therefore, administrators should design more targeted activities during activities so that employees can have opportunities to exert their abilities and it can also provide opportunities for administrators to find talents. Administrators must cultivate the talents so that they can give full play to their talents and improve enterprises' economic benefits.

Formulating scientific talent recruitment mechanism. Talents flow will bring different degrees of losses. In order to reduce this loss to the minimum, enterprise must formulate scientific talent recruitment mechanism. If they are to recruit staff of general posts, they can simplify corresponding procedures and help reduce enterprises"' expenditure. If they are to hire talents of important posts, they can add procedures of the recruitment correspondingly so that employers can have more understanding of the applicants so as to guarantee quality of the employed staff. They should observe and cultivate the recruited employees and reduce employees' time of adapting to work.

Formulating standard talent incentive system. In order to improve employees' working enthusiasm and improve employees' responsibility, enterprises must formulate standard talent incentive system. Specifically, they can start from the following aspects: firstly, employees that perform excellently in work should be given awards in time, which can be materials or post promotion. In this way, it can not only give more impetus to people who receive the awards so that other employees can learn from excellent employees and it contributes to improvement of economic benefits of the enterprises. Secondly, administrators can allocate capital, management and technology and other production factors reasonably. If enterprises receive good benefits, employees should receive corresponding performance pay so as to guarantee that performance of enterprises is in direct proportion to employees' salary; in this way, employees will work hard in order to increase salary and enterprise will receive more benefits and realize win-win[7]. Thirdly, after establishing management system, it should be completed continuously. Management system should include employees' work assessment evaluation and employees with excellent performance should be awarded while employees that endanger enterprises' benefits must be punished accordingly so as to complete management system. Complete management system must be established and reasonable assessment and evaluation must be completed to employees so as to stimulate employees' initiative and enthusiasm, strengthen their responsibility and be responsible to enterprises.

Increasing professional skills continuously. Besides relative trainings to employees, enterprises' administrators must improve their own management abilities continuously and complete their human resource management knowledge. They should not only grasp relative basic knowledge but also know foreign theories about human resource management. Also, they should apply these theories into practice, strengthen communication among administrators, communicate 
with administrators from other enterprises, discuss more effective management experiences and make sure their own enterprises' development strategy so as to improve working efficiency from various aspects. They should formulate unified standard for employees' training plan, formulate complete recruitment and appointment post system, pay attention to employees' post training and improve working efficiency so as to realize enterprises' economic benefits.

\section{Conclusion}

From the analysis, we can see how important human resource management to enterprises' development. At present, because of the rapid and stable development of economic society, Chinese marketing economy is facing pressure of transition. In order to stand out from competitions and win a space from fierce competitions, enterprises must complete human resource management measures continuously, strengthen attention on human resource management and employees so that employees have stronger sense of belonging and they are willing to contribute all their power to enterprises. Only by this can it guarantee that enterprises are invincible in fierce competitions.

\section{References}

[1] L.B. Sun. Application of Human Resource Systematic Management in Business Management. Modern Communication,2014,04:1.

[2] C.H. Guo. Analysis of Human Resource Systematic Management in Business Management Measures.Office Business,2014,15:12.

[3] Y. Yan. Analysis of Application of Human Resource Systematic Management in Business Management.Administrators,2015,07:203.

[4] Z.G. Wen. Application of Human Resource and Human Resource Systematic Management. Administrators,2013,10:120.

[5] X.M. Jin, J.H. Zhang. Application of Human Resource Systematic Management in Enterprises. Cooperative Economy and Science,2014,23:99.

[6] X. Wu. Effective Measures of Corporate Human Resource Systematic Management. Science and Technology Outlook,2015,09:161.

[7] Y. Huang. Application of Systematic Human Resource Management in Enterprises. Private Science and Technology,2015,08:107. 